\title{
Bazzanene, a Sesquiterpene Hydrocarbon of a New Carbon Skeleton from Bazzania pompeana (Lac.) Mitt.
}

A sesquiterpene hydrocarbon of a new carbon skeleton was isolated from the essential oil of Bazzania pompeana (Lac.) Mitt., and its structure was determined as formula (I). We propose the name bazzanene for this hydrocarbon, and the evidences for the proposed structure are described here.

Bazzanene was isolated in a pure state with respect to gas and thin-layer chromatography by means of fractional distillation and successive elution chromatography using silica gel impregnated with silver nitrate. This compound, $\mathrm{C}_{15} \mathrm{H}_{24}$, showed the following physical properties: bp $102-103^{\circ} / 2$ Torr; $[\alpha]_{\mathrm{D}}^{25}+48.0^{\circ} ; v_{\max }^{\text {liq }} 1647$, $886 \mathrm{~cm}^{-1}\left(-\mathrm{C}=\mathrm{CH}_{2}\right), 806 \mathrm{~cm}^{-1}(\stackrel{\mathrm{l}}{\mathrm{C}}=\stackrel{\mathrm{C}}{\mathrm{C}} \mathrm{H})$ and 1379,1369

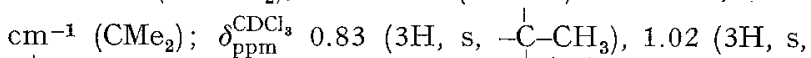
$\left.-\stackrel{+}{\mathrm{C}}-\mathrm{CH}_{3}\right), 1.64\left(3 \mathrm{H}, \mathrm{d}, J=1.2 \mathrm{~Hz}, \stackrel{\stackrel{\mathrm{C}}{\mathrm{C}}-\mathrm{l}}{\mathrm{C}} \mathrm{H}_{3}\right), 4.83,4.96$ (each $1 \mathrm{H}, \mathrm{s},-\mathrm{C}=\mathrm{CH}_{2}$ ) and $5.32(1 \mathrm{H}, \mathrm{m},-\stackrel{\mathrm{C}}{\mathrm{C}}=\mathrm{CH}) ; \mathrm{M}^{+}$peak $\mathrm{m} / \mathrm{e} 204(5 \%)$, base peak m/e 109, next highest peak $\mathrm{m} / \mathrm{e} 67(31 \%)$ and third highest peak $\mathrm{m} / \mathrm{e} 93(25 \%)$.

This hydrocarbon took up 2 moles of hydrogen in catalytic hydrogenation over the Adams catalyst in acetic acid to produce a saturated tetrahydro compound, $\mathrm{C}_{15} \mathrm{H}_{28}\left(\mathrm{M}^{+}\right.$peak $\mathrm{m} / \mathrm{e} 208$ and base peak $\mathrm{m} / \mathrm{e} \mathrm{96)}$, and heating with palladium-charcoal in a sealed tube it produced cuparene (II) in a good yield, which was identified by IR-, NMR- and mass-spectrometry.

Bazzanene is thus deduced to be a bicyclic sesquiterpene hydrocarbon which bears one geminal dimethyl, one methyl on a double bond and one exo-methylene and gives cuparene on dehydrogenation. As such structures, only 3 carbon skeletons (III), (IV) and (V) are probable. Among these skeletons, (IV) is himachalane ${ }^{1}$ and (V) is chamigrane ${ }^{2}$, and IR- and mass-spectra of both these compounds did not coincide with those of the saturated

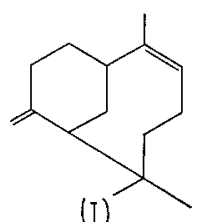

(1)<smiles>CC1(C)CCCC1(c1ccccc1)c1ccc(F)cc1</smiles>

(II) compound of bazzanene. Therefore, bazzanene can be considered to have a carbon skeleton of (III), which is also supported by the following fact: both himachalane and chamigrane exhibited a base peak at $\mathrm{m} / \mathrm{e} 124$, whereas the tetrahydro product of bazzanene exhibited it at. $\mathrm{m} / \mathrm{e} 96$ together with a characteristic peak at $\mathrm{m} / \mathrm{e} 111$ $(51 \%)$, to which the fragment ions (VI) and (VII) expected from structure (III) can be assigned.

Bazzanene was oxidized with sodium dichromate in acetic acid to produce an $\alpha, \beta$-unsaturated ketone, $\mathrm{C}_{15} \mathrm{H}_{22} \mathrm{O}$ (calcd. $\mathrm{m} / \mathrm{e} 218.167$, obsd. $\mathrm{m} / \mathrm{e} 218.166$ ), $\nu_{\max }^{\text {liq }}$ $1672 \mathrm{~cm}^{-1}, \quad \lambda_{\max }^{\mathrm{EtOH}} 239 \mathrm{~nm}$ ( $\varepsilon 8300$; calcd. $239 \mathrm{~nm}$ for $\left.\mathrm{CH}_{3}-\mathrm{C}=\mathrm{CH}-\mathrm{CO}-\right)$. The NMR-spectrum, $\delta_{\max }^{\mathrm{CDCl}_{3}} 0.99(3 \mathrm{H}$, s, $\left.\stackrel{\text { I }}{\mathrm{I}}-\mathrm{CH}_{3}\right), 1.09\left(3 \mathrm{H}, \mathrm{s}, \stackrel{\mathrm{C}}{\mathrm{C}}-\mathrm{CH}_{3}\right), 1.74\left(3 \mathrm{H}, \mathrm{d}, J=1.5 \mathrm{H}_{2}\right.$, $\left.-\mathrm{C}=\mathrm{C}-\mathrm{CH}_{3}\right), 2.33\left(2 \mathrm{H}, \mathrm{d}, J=1.0 \mathrm{~Hz},-\mathrm{CH}_{2}-\mathrm{CO}-\right), 4.83$, $5.02\left(\right.$ each $\left.1 \mathrm{H}, \mathrm{s},-\mathrm{C}=\mathrm{CH}_{2}\right)$ and $6.50(1 \mathrm{H}, \mathrm{m},-\mathrm{C}=\mathrm{CH}-\mathrm{CO}-)$, $\mathrm{m} / \mathrm{e} 95\left(100 \%, \mathrm{C}_{7} \mathrm{H}_{11}\right.$ : calcd. $\mathrm{m} / \mathrm{e} 95.086$, obsd. $\mathrm{m} / \mathrm{e}$ $95.086)$ (IX) and $\mathrm{m} / \mathrm{e} 123\left(77 \%, \mathrm{C}_{8} \mathrm{H}_{11} \mathrm{O}\right.$ : calcd. $\mathrm{m} / \mathrm{e}$ 123.081, obsd. m/e 123.082) (X), can be explained by structure (VIII) expected for the oxidized product of structure (I).

Therefore, bazzanene must be 2,6,6-trimethyl-8methylene bicyclo[5.3.1] undec-2-ene. This is the first example of a bicyclo[5.3.1]undecane system in sesquiterpene compounds.

Zusammenfassung. Aus dem essentiellen Öl von Bazzania pompeana (Lac.) Mitt. wurde Bazzanen, ein Sesquiterpen-Kohlenwasserstoff mit einem neuartigen Kohlenstoffgerüst, isoliert. Bazzanen besitzt die Struktur des 2, 6, 6-Trimethyl-8-methylen bicyclo[5.3.1.]undec-2ens.

S. Hayashi, A. Matsud and T. Matsuura

Department of Chemistry,

Faculty of Science, Hiroshima University,

Hiroshima (Japan), 23 Jine 7969 and the characteristic peaks of the mass spectrum,<smiles>CC1CCCC(C)C2CC1CCC2(C)C</smiles>

(III)<smiles>CC1CCC2C(C)CCCC(C(C)(C)C)C2C1</smiles>

(N)<smiles>CC1CCC2(CCCC(C)C2)CC1</smiles>

(V)
1 T. C. Joseph and Sukr Dev, Tetrahedron 24, 3809 (1968). - Y. Hirose, Shitsuryo Bunseki 15, 162 (1967). - H. N. Subba, N. P. Damodaran and Sukh Dev, Tetrahedron Letters 1968 , 2213.

2 S. TTo, K. Endo, T. Yoshida and M. KopdaMa, Chem. Commun. 1967, 186. - Y. Orta and Y. Hirose, Tetrahedron Letters 1968 , 2483. - Y. OHTA, private communication.

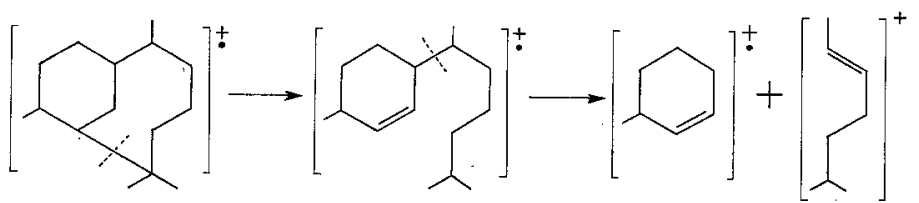

(VI)
(VI)<smiles>C=C1CCC(/C(C)=C\C(CC(C)(C)C)=NC2C=CCCC2)CC1</smiles>

(VII) 